\title{
BEACH NOURISHMENT THEORY AND PRACTICE
}




\title{
ADVANCED SERIES ON OCEAN ENGINEERING
}

\author{
Series Editor-in-Chief \\ Philip L- F Liu (Cornell University)
}

Vol. 4 Coastal Bottom Boundary Layers and Sediment Transport by Peter Nielsen (Univ. Queensland)

Vol. 5 Numerical Modeling of Ocean Dynamics by Zygmunt Kowalik (Univ. Alaska) and T S Murty (Inst. Ocean Science, BC)

Vol. 6 Kalman Filter Method in the Analysis of Vibrations Due to Water Waves by Piotr Wilde and Andrzej Kozakiewicz (Inst. Hydroengineering, Polish Academy of Sciences)

Vol. 7 Physical Models and Laboratory Techniques in Coastal Engineering by Steven A. Hughes (Coastal Engineering Research Center, USA)

Vol. 8 Ocean Disposal of Wastewater by lan $R$ Wood (Univ. Canterbury), Robert $G$ Bell (National Institute of Water \& Atmospheric Research, New Zealand) and David L Wilkinson (Univ. New South Wales)

Vol. 9 Offshore Structure Modeling by Subrata K. Chakrabarti (Chicago Bridge \& Iron Technical Services Co., USA)

Vol. 10 Water Waves Generated by Underwater Explosion by Bernard Le Méhauté and Shen Wang (Univ. Miami)

Vol. 11 Ocean Surface Waves; Their Physics and Prediction by Stanislaw $R$ Massel (Australian Inst. of Marine Sci)

Vol. 12 Hydrodynamics Around Cylindrical Structures by $B$ Mutlu Sumer and Jørgen Fredsøe (Tech. Univ. of Denmark)

Vol. 13 Water Wave Propagation Over Uneven Bottoms Part I - Linear Wave Propagation by Maarten $W$ Dingemans (Delft Hydraulics)

Part II - Non-linear Wave Propagation by Maarten W Dingemans (Delft Hydraulics)

Vol. 14 Coastal Stabilization by Richard Silvester and John R C Hsu (The Univ. of Western Australia)

Vol. 15 Random Seas and Design of Maritime Structures (2nd Edition) by Yoshimi Goda (Yokohama National University)

Vol. 16 Introduction to Coastal Engineering and Management by $J$ William Kamphuis (Queen's Univ.)

Vol. 17 The Mechanics of Scour in the Marine Environment by $B$ Mutlu Sumer and Jørgen Fredsøe (Tech. Univ. of Denmark)

Vol. 18 Beach Nourishment: Theory and Practice by Robert G. Dean (Univ. Florida)

Vol. 19 Saving America's Beaches: The Causes of and Solutions to Beach Erosion by Scott L. Douglass (Univ. South Alabama) 
Advanced Series on Ocean Engineering - Volume 18

\section{BEACH NOURISHMENT THEORY AND PRACTICE}

\section{Robert G. Dean}

University of Florida, USA 


\section{Published by}

World Scientific Publishing Co. Pte. Ltd.

5 Toh Tuck Link, Singapore 596224

USA office: Suite 202, 1060 Main Street, River Edge, NJ 07661

UK office: 57 Shelton Street, Covent Garden, London WC2H 9HE

\section{British Library Cataloguing-in-Publication Data}

A catalogue record for this book is available from the British Library.

\section{BEACH NOURISHMENT: THEORY AND PRACTICE}

Copyright $\odot 2002$ by World Scientific Publishing Co. Pte. Ltd.

All rights reserved. This book, or parts thereof, may not be reproduced in any form or by any means, electronic or mechanical, including photocopying, recording or any information storage and retrieval system now known or to be invented, without written permission from the Publisher.

For photocopying of material in this volume, please pay a copying fee through the Copyright Clearance Center, Inc., 222 Rosewood Drive, Danvers, MA 01923, USA. In this case permission to photocopy is not required from the publisher.

ISBN 981-02-1547-9

ISBN 981-02-1548-7 (pbk)

This book is printed on acid-free paper.

Printed in Singapore by Uto-Print 


\section{Foreword}

The goals of this book on beach nourishment are to be reasonably comprehensive and to find application in the designer's office, in the classroom, to be readable by and of general interest to the layperson and to provide a starting point for researchers. As a formal technology, beach nourishment is fairly young having only achieved solid physical underpinnings and predictive capabilities in the last decade or so. Although our capabilities to design projects effectively has improved substantially, most projects still perform in some detail different than or to a degree which was not anticipated in the design phase. Thus, beach nourishment continues to offer many fascinating research challenges. These projects can be considered as large scale perturbations to the natural nearshore system which the natural forces commence to modify in both the cross-shore and longshore directions. The nourishment sand is usually not of the same size characteristics as the native and will approach a profile that is unique to its gradation. The time scales of this cross-shore equilibration and evolution of the planform perturbation are of considerable importance to the designer and the sponsor in assessing the economic viability of the project. Although the economic viability of a beach nourishment project depends to a substantial degree on the value of the upland property being protected, a project requiring renourishment at two year intervals will probably not be economically justified whereas if the renourishment interval is five to seven years, the project will be judged a success.

The benefits of beach nourishment can include storm damage reduction, recreation and environmental enhancement. A wide beach serves as both an effective energy absorber during periods of elevated water levels and storm waves and also provides a reservoir of sand which can be transported and 
deposited offshore as a bar on which the larger waves break thereby further reducing the wave energy which reaches the shore. As will be seen later, the reductions in wave height and wave forces due to relatively small additional beach widths are surprisingly large! Tourists are attracted to beaches and a wide recreational beach can result in a significant increase in tourist related income to resort areas. Many beaches considered for nourishment have been stabilized by hard structures: seawalls and/or revetments, possibly in combination with groins leaving little sea turtle nesting habitat. Most nourishment projects constructed in areas where turtle nesting occurs require fairly comprehensive monitoring and possible nest relocation programs. In general, where the project provides a wide berm where there was previously little nesting habitat, nesting density has increased markedly. In areas where suitable habitat existed prior to the project, the monitoring results indicate that the turtles are affected negatively to a relatively minor degree during the first year following project construction and in subsequent years the nesting density may increase slightly above or be indistinguishable from pre-project conditions.

A relevant comment regarding beach nourishment is that much misinformation has been disseminated regarding the effectiveness of this shore protection method. The statement that "the project will wash away with the first good storm" has been frequently expressed. Beach nourishment has now been performed and monitored in the United States on several significant projects for up to nearly thirty years. Analysis of these data suggests a far different assessment of project performance and provides a basis for evaluating and improving design methodology. The test of the efficacy of a methodology (beach nourishment in this case) is reflected in whether its use is continued over the years. By this measure, beach nourishment has been quite effective as it is being applied as a method for shore protection and stabilization on an increasing and continuing basis.

Prior to nourishment, shorelines are in quasi-equilibrium with the waves and offshore bathymetry. Offshore borrow pits from which sand is removed for nourishment can represent substantial perturbations to the nearshore bathymetry, lowering the profile by one to 6 meters over plan areas of one or more square kilometers. Through wave modification, this depth perturbation has the potential to cause a modified equilibrium planform with shoreline recession in some areas and advancement in others. These borrow 
pits are one of many possible causes of localized erosional zones, termed "erosional hot spots" which are of considerable concern in design.

The actual (documented through monitoring) performance of a beach nourishment project vis a vis its predicted performance is of interest to individuals ranging from laypersons to the design engineer to the public official who promoted (or resisted!) the expenditure of funds to construct the project. Thus, considerable effort is devoted in later chapters to first develop predictive techniques and later to evaluate these by comparison with monitoring results. Predictions can be carried out with relatively simple models which is the primary focus of this book or with very detailed numerical models. It will be shown that our capability to predict the performance of beach nourishment projects with the simple models is almost as good, or in some cases better, than the more complex models. It is anticipated that predictions conducted with the more complex models will improve considerably over the coming decades. In general, predictability is much better for the overall performance of the project than, for example, the performance at a particular location within or adjacent to the project. Finally, predictability depends significantly on the setting of the project and on the "match" between the native and nourishment sediments. Projects nourished with compatible sediments on a long straight shoreline are relatively insensitive to wave direction and the planform centroid remains nearly fixed. It can be demonstrated that the planform centroid of a project migrates if the project is located near a littoral barrier and/or if the project is constructed in the presence of oblique waves with sediment characteristics that are different than the native.

A note on the organization of this book is appropriate. An attempt has been made to use the appendices as repositories for the technical details which may be valuable to students and researchers but would be of little interest (or even discouraging) to designers and laypersons. Thus in many cases, the phenomena and results which are applicable to understanding and design are presented in the main body of the text and the development which may be required for detailed understanding or of research interest are the subjects of individual appendices.

There are several good references and sources containing valuable background and detail relating to beach nourishment. The National Research 
Council (NRC, 1995) report on "Beach Nourishment and Protection" provides a comprehensive evaluation of the methodology and constraints as of 1995. The volume "Beach Nourishment: Engineering and Management Considerations" edited by Stauble and Kraus (1993) includes a number of relevant papers. The report "Manual on Artificial Beach Nourishment" published by the Delft Hydraulics Laboratory of the Netherlands (1987) also provides a comprehensive assessment at that time. The proceedings of the "Beach Technology Conferences" published by the Florida Shore and Beach Preservation Association contain a large number of case studies of beach nourishment projects. Some articles in Shore and Beach also provide nontechnical discussions and case studies of particular value to the layperson. Finally the proceedings of the biennial International Conferences on Coastal Engineering contain a broad range of nourishment papers with descriptions of international case studies.

Beach nourishment literature includes both the metric (International) and customary English systems of units. Because the student and practitioner of beach nourishment will encounter both systems of units, this book will utilize both systems in the case studies and examples presented. Table F.1, below provides several useful conversion factors.

Table F.1. Useful conversion factors between metric and Customary English Units found in beach nourishment literature.

\begin{tabular}{lccc}
\hline \multicolumn{1}{c}{ To convert } & From & To & Multiply by \\
\hline Distance & $\mathrm{m}$ & $\mathrm{ft}$ & 3.28 \\
Distance & $\mathrm{ft}$ & $\mathrm{m}$ & 0.305 \\
Distance & $\mathrm{km}$ & $\mathrm{miles}$ & 0.621 \\
Distance & $\mathrm{miles}$ & $\mathrm{km}$ & 1.610 \\
Volume & $\mathrm{m}^{3}$ & cubic $\mathrm{yards}^{2} \mathrm{yd}^{3}$ & 1.307 \\
Volume & $\mathrm{ybic}$ & $\mathrm{m}^{3}$ & 0.765 \\
Volume density & $\mathrm{m}^{3} / \mathrm{m}$ & $\mathrm{yd}^{3} / \mathrm{ft}$ & $0.398(\approx 0.40)$ \\
Volume density & $\mathrm{yd}^{3} / \mathrm{ft}$ & $\mathrm{m}^{3} / \mathrm{m}$ & $2.51(\approx 2.50)$ \\
Longshore diffusivity, $G$ & $\left.\mathrm{~m}^{2} / \mathrm{sec}^{2}=\mathrm{m}^{2} / \mathrm{s}\right)$ & $\mathrm{ft}^{2} / \mathrm{s}$ & 10.75 \\
Longshore diffusivity, $G$ & $\mathrm{ft}^{2} / \mathrm{s}$ & $\mathrm{m}^{2} / \mathrm{s}$ & 0.093 \\
Longshore diffusivity, $G$ & $\mathrm{~m}^{2} / \mathrm{s}$ & $\mathrm{km}^{2} / \mathrm{year}$ & 31.54 \\
Longshore diffusivity, $G$ & $\mathrm{ft}^{2} / \mathrm{s}$ & $\mathrm{mile}^{2} / \mathrm{year}$ & 1.13 \\
\hline
\end{tabular}




\section{References}

Delft Hydraulics Laboratory (1987), "Manual on Artificial Beach Nourishment," Rijkswaterstaat, The Delft Hydraulics Laboratory Centre for Civil Engineering Research, Codes and Specifications, Report No. 130, 195pp.

National Research Council (1995), "Beach Nourishment and Protection," National Academy Press, Washington, DC, 334pp.

Stauble, D. K. and Kraus, N. C. (eds.) (1993), Special Volume on "Beach Nourishment Engineering and Management Considerations," Proceedings, Coastal Zone Management, American Society of Civil Engineers. 
This page is intentionally left blank 


\section{Acknowledgments}

The Author is indebted to several agencies and many individuals for providing opportunities and motivation for him and his students to explore the fascinating field of the large scale sediment transport processes associated with beach nourishment projects. Equally appealing to an engineer is the possibility of stabilizing otherwise eroding shorelines through beach nourishment, thus rendering a service to the general public. Opportunities have included monitoring large scale projects over a number of years, analyzing and interpreting data which we or others have collected and designing a number of projects and observing their evolution over time. Perhaps most rewarding is the conclusion that, designed and constructed properly, these projects function effectively!

The two agencies owed the greatest debt are the State of Florida Beaches Program within the Department of Environmental Protection and the U.S. Department of Commerce's Sea Grant Program, both of which have provided sustained funding over several decades which allowed pursuit of either specific related research topics or documentation of the performance of particular projects. Those individuals who have contributed to motivation and stimulating discussions cannot all be acknowledged properly here; however, I will mention a few. M. P. O'Brien (deceased) is remembered as a great inspiration due to his curiosity, interpretative capabilities and stimulating discussions. Professor Bob Wiegel has encouraged the collection of large scale field data and emphasized its significance. Tony Dalrymple has always provided encouragement and interesting discussions on topics ranging from waves to sediment transport. His physical insight and facility with mathematics enable him to contribute in unique ways. Bob Dolan was instrumental in the arrangement of a five year field study opportunity on 
the large scale Perdido Key, FL project. Tom Campbell, an active supporter and practitioner of beach nourishment technology, has provided observations, interpretation and insight relating to project performance and evolution that have been invaluable. Finally, to the many students who participated in the field and laboratory studies of beach nourishment, my heartfelt "thanks" for your support and contributions!

Robert G. Dean

December 30, 2001 


\section{Contents}

Foreword $\quad$ v

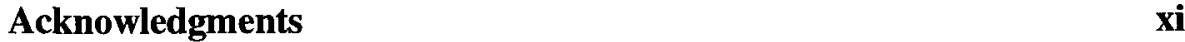

1 Introduction 1

1.0 General 1

References 4

2 Methods of and Dredging Equipment for

Beach Nourishment 5

2.0 Introduction 5

2.1 Dredge Placement and Dredge Types 5

2.1.1 Pipeline Dredges 6

2.1.2 Hopper Dredges 10

2.2 Management of Dredge Material on the Beach 13

2.3 Nourishment by Truck Haul 13

2.4 Placement by Conveyor Belts 14

2.5 Sand Bypassing Systems 15

2.5.1 Sand Bypassing with Conventional Pump Systems 15

2.5.2 Sand Transfer Using Jet Pumps 17

References $\quad 19$

3 Tools for Later Use $\quad 21$

$\begin{array}{ll}3.0 \text { General } & 21\end{array}$

3.1 Terminology 21

3.1.1 Beach Nourishment 22

3.1.2 Borrow Area 22

3.1.3 Sediment Compatibility 23 
3.1.4 Nourishment Volume Density

3.1.5 Closure Depth

3.1.6 Background Erosion 24

3.1.7 Evolutionary Processes 24

3.2 General Design Considerations $\quad 26$

3.2.1 Introduction 26

3.2.2 The Dutch Method of Design 26

3.2.3 Some Practical Considerations 27

$\begin{array}{ll}3.3 \text { Cross-Shore Considerations } & 29\end{array}$

3.3.1 Equilibrium Beach Profiles 29

3.3.2 Closure Depth 34

3.3.3 Shoreline Response as a Result of Sediment Gains or Losses

$\begin{array}{lll}3.4 & \text { Planform Considerations } & 37\end{array}$

3.4.1 General 37

3.4.2 Longshore Sediment Transport 37

3.5 The Pelnard-Considère Equation 40

3.5.1 General 40

3.5.2 Conservation of Sediment 40

3.5.3 Linearized Transport Equation 41

3.5.4 Combined Equations 41

3.5.5 Effect of Wave Refraction 45

3.6 Some Solutions of and Results Obtained from the

Pelnard-Considère Equation 45

3.6.1 General 45

3.6.2 Elementary Solution 46

3.6.3 Initial Rectangular Planform on an Infinitely Long Shoreline $\quad 47$

3.6.4 Impoundment by a Littoral Barrier 52

3.6.5 Periodic Bypassing Around a Barrier $\quad 55$

3.6.6 Insensitivity of Total Beach Nourishment Evolution to Storm Sequencing $\quad 58$

$\begin{array}{lll}3.7 & \text { Longshore Diffusivity } & 59\end{array}$

3.8 Nourishment on Irregular Shorelines and Bathymetry with Nonuniform Shoreline Changes $\quad 60$

3.8.1 Numerical Model Applied to Actual Bathymetry 62 
3.8.2 Simple or Numerical Model Applied to Transformed Bathymetry

3.8.2.1 Case 1. Long irregular shoreline and bathymetry with uniform background erosion, compatible sediment, no structures

3.8.2.2 Case 2. Long irregular shoreline and bathymetry with nonuniform background erosion, compatible sediment, no structures

3.8.2.3 Case 3. Same as Case 2, except one or more structures

3.8.2.4 Case 4. Nourishment downdrift of a littoral barrier

3.8.2.5 Case 5. Pocket beach 66

$\begin{array}{lll}3.9 & \text { Summary of Chapter } 3 & 67\end{array}$

References $\quad 68$

4 Performance Measures and Prediction 71

4.0 Performance Measures 71

4.1 Predictability of Beach Nourishment Physical Performance 72

$\begin{array}{ll}\text { References } & 74\end{array}$

5 Additional Cross-Shore Considerations $\quad 75$

$\begin{array}{ll}5.0 \text { Introduction } & 75\end{array}$

5.1 Equilibrium Shoreline Advancement 75

5.1.1 Compatible Sand 76

5.1.2 Nourishment Sands Finer or Coarser than the Native 76

5.2 Characteristics of Contour Advancement 87

5.2.1 Intersecting Profiles $\quad 87$

5.2.2 Nonintersecting Profiles $\quad 89$

5.2.3 Submerged Profiles $\quad 89$

5.2.4 Application of Differences in Contour Positions for Purposes of Interpretation $\quad 90$

5.3 Equilibrium Beach Profiles for Nonuniform Nourishment Sand Sizes 93

5.4 Nourishment Sediments Represented by Two Sizes 94 
5.5 Reduction in Beach Width Due to Profile Equilibration 97

5.5.1 Introduction $\quad 97$

5.5.2 Equations Representing Profile Reduction 97

$\begin{array}{lll}5.5 .3 \text { Results } & 99\end{array}$

5.5.4 Time Scales for Profile Equilibration 103

5.6 Examples Illustrating Material Presented in this Chapter 106

5.6.1 Example 1 106

5.6.2 Example 2 108

5.7 Examples Combining Material Presented in this and $\begin{array}{ll}\text { Previous Chapters } & 109\end{array}$

$\begin{array}{lll}\text { 5.7.1 Example 3 } & 109\end{array}$

5.7.2 Example 4 111

5.7.3 Example 5 113

5.7.4 Example 6 113

5.8 Summary of Chapter 5 114

References 115

6 Additional Planform Considerations 117

$\begin{array}{ll}6.0 \text { Introduction } & 117\end{array}$

6.1 Nourishment on Barrier Islands 117

6.1.1 Case (a). Nourishment on Full Length of Barrier Island

6.1.2 Case (b). Nourishment on Central Portion of Barrier Island

6.1.3 Case (c). Nourishment Extending from One End of a Long Barrier Island

6.1.4 Case (d). Nourishment Starting Near One End of a Long Barrier Island

6.2 Background Erosion Rate, $e(x, t)$

6.2.2 Rectangular Planform Nourishment with Uniform Background Erosion: Long Straight Beach

6.2.3 Early Performance of an Initially Rectangular Project with a Uniform Background Erosion Rate

6.2.4 Rectangular Planform Nourishment with Uniform Background Erosion: One End Adjacent to an Inlet 
6.3 Erosional Hot Spots 128

6.4 Nourishment in the Presence of Seawalls 130

6.5 Effects of Sediment Size on Nourishment Planform Evolution

6.6 Effects of Sediment Size on Dry Beach Area Evolution 134

6.7 Multiple Nourishments

6.7.1 General

6.7.2 Results Based on Assumed Exponential Decay

6.7.3 Results Based on Pelnard-Considère Equation

6.8 Placement Strategies

6.8.1 Effect on Longevity of Setting Back the Fill Ends from Project Boundaries

6.8.2 Beach Nourishment Projects with Tapered Ends 145

6.8.3 Optimum Placement Strategy 152

6.9 Field Projects 155

6.9.1 Delray Beach, FL 155

6.9.2 Nourishment Downdrift of a Littoral Barrier 156

6.10 Numerical Modeling of Beach Nourishment Planform

Evolution

Exercises

References

7 Borrow Area Considerations $\quad 173$

$\begin{array}{lll}7.1 \text { Introduction } & 173\end{array}$

7.2 General Characteristics and Examples of Borrow Pits 174

7.2.1 Borrow Area Establishment 174

7.2.2 Geometry of Borrow Areas 175

7.2.3 Quantification of Rocks in the Borrow Area 179

$\begin{array}{ll}\text { 7.2.4 Nourishment Sand Color } & 181\end{array}$

7.2.5 Effects of Borrow Pits on Adjacent Beaches 181

7.2.6 Use of Ebb Tidal Shoals as Borrow Sites 182

References $\quad 184$

8 Costs and Benefits of Beach Nourishment 185

$\begin{array}{lll}8.1 \text { Introduction } & 185\end{array}$

8.2 Costs 185

8.3 Benefits 186 
8.3.1 General

8.3.2 Storm Damage Reduction

8.3.3 Recreational Benefits

8.3.4 Property Appreciation Benefits

8.4 Change in Overall Benefits as Project Evolves

References

9 Environmental Effects of Beach Nourishment

9.1 Introduction

9.2 Short- and Long-Term Impacts

9.3 Positive Effects of Beach Nourishment

9.4 Biota and Effects Considered

9.4.1 Sea Turtles

9.4.1.1 Beach hardness

9.4.1.2 Tilling to reduce beach hardness

9.4.1.3 Nest relocation

9.4.1.4 Monitoring of the Martin County,

FL beach nourishment project

9.4.1.4.1 General nesting trends

9.4.1.4.2 Effect of additional beach width on nesting activities

9.4.1.4.3 Effects of beach scarps

9.4.1.4.4 Effects of beach compactness

9.4.1.4.5 Effect of beach tilling

9.4.1.4.6 Effects of darker sediments

9.4.2 Effects of Beach Nourishment on Beach Infauna

9.4.3 Fishes

9.4.3.1 General

9.4.3.2 Detailed study in New Jersey

9.5 Rock Outcrops

9.6 Borrow Areas

9.7 Summary Statement

References

10 Monitoring of Beach Nourishment Projects

10.1 Introduction

10.2 Performance Monitoring
186

186

189

190

191

193

195

195

196

196

196

197

199

202

205

207

209

210

210

210

211

212

212

213

213

213

214

215

216

216

219

219

221 
10.2.1 General 221

10.2.2 Establishment of a Baseline 222

10.2.3 Beach and Offshore Profile Surveys 222

10.2.4 Sand Samples 226

10.2.5 Aerial Photographs 226

10.3 Monitoring for Generic (Research) Purposes 227

10.4 Establishment of Thresholds 227

10.5 Summary 228

References $\quad 229$

11 Case Studies $\quad 231$

11.0 Introduction 231

11.1 Review of Individual Projects 231

11.1.1 Perdido Key, Florida 232

11.1.1.1 Physical monitoring 234

11.1.1.1.1 Beach nourishment 234

11.1.1.1.2 Profile (or underwater berm) nourishment 239

11.1.1.2 Benthic studies 240

11.1.1.3 Vegetation studies 242

11.1.1.4 Perdido Key beach mouse 244

11.1.1.5 Prediction of project performance using simple methodology 245

11.1.1.5.1 General 245

11.1.1.5.2 Methodology and results 245

11.1.1.6 Summary of Perdido Key project 246

11.1.2 Folly Beach, South Carolina Beach Nourishment 247

11.1.2.1 General project description 247

11.1.2.2 Volumetric performance 248

11.1.2.3 Plan area performance 251

11.1.3 Martin County, FL Project 251

11.1.3.1 Simple design $\quad 254$

11.1.4 Anna Maria Key, FL 257

11.1.4.1 General 257

11.1.4.2 Description of beach nourishment project $\quad 257$

11.1.4.3 Design basis 257

11.1.4.4 Simple design results 261 
11.1.5 Delray Beach, $F L$

11.1.6 Midtown Beach, FL 266

References

Appendix A Effects of Idealized Wave Refraction

by Nourishment Projects

273

Appendix B Decomposition of Total Transport into

Background and Project Component

277

Appendix C Nourished Profiles Represented by a

Distribution of Sediment Sizes

283

Appendix D Composite Sand Characteristics 295

Appendix E Erosional Hot Spots 305

Appendix F Nourishment Along a Seawalled Coast

327

Appendix G Shoreline Changes Downdrift of a Littoral

Barrier with Periodic Bypassing

Appendix $\mathbf{H}$ Effects of Sand Size on Evolution of

Nourished Beaches

Appendix I Mechanics of Hydraulic Dredging

Appendix J Storm Damage Reduction Potential by

Beach Nourishment

371

Appendix K Probability of Encountering Rock with

Cores through a Borrow Pit

381

Author Index

391

Subject Index

395

Location Index 